\title{
Verification of the Safety of Storing a Pair of Pressure Vessels
}

Vít Černohlávek (0000-0001-6816-1124) ${ }^{1}$, Jan Štěrba (0000-0002-2676-3562)1, Martin Svoboda (0000-0002-73441531) ${ }^{1}$, Tomáš Zdráhal (0000-0001-8638-1948) ${ }^{1}$, Marcin Suszyński (0000-0001-7926-0574) ², Milan Chalupa (00000002-9366-1371) ${ }^{3}$, Zdeněk Krobot (0000-0002-7911-5577)3

${ }^{1}$ Faculty of Mechanical Engineering, J. E. Purkyne University in Usti nad Labem. Pasteurova 3334/7, 40001 Usti nad Labem. Czech Republic. E-mail: vit.cernohlavek@ujep.cz, jan.sterba@ujep.cz, martin.svoboda@ujep.cz, tomas.zdrahal@ujep.cz

${ }^{2}$ Faculty of Mechanical Engineering, Poznan University of Technology, Poland. E-mail: marcin.suszynski@put.poznan.pl

${ }^{3}$ Faculty of Military Technology, University of Defence in Brno, Czech Republic, milan.chalupa@unob.cz, zdenek.krobot@unob.cz

This article deals with the calculation of pressure vessels for beer maturation using analytical calculation according to ČSN standards and with the help of commercial software PVESS. The article presents commonly used procedures in the design of pressure vessels, resp. vessels for use in the brewing industry in the assembly of pressure vessels stacked on top of each other. The article describes the main parts of the brewery tanks, including the procedure for their design. The choice of materials used, the choice of basic dimensions of pressure vessels was determined in the work. The tank vessel is made of stainless steel 1.4301 or 1.4541 . The advantages of this material in the brewing industry are also presented. From the given input parameters, a control calculation of the strength of pressure vessels was performed. The result of the work was the verification of the calculation, finding out the deviations of the measurements using mathematical software with a common calculation according to the valid standards for the calculation of pressure vessels.

Keywords: lager tank, storage, bottom, construction, pressure vessel, stainlees steel

\section{Introduction}

The lager tank is intended for the fermentation and maturation of young beer in the lager cellar. Here, the beer is fermented at low temperatures, clarified, matured and saturated with the resulting carbon dioxide under pressure. To maintain the correct temperature during the process of maturing young beer, the tank can be equipped with two cooling zones, which are located on the outer shell of the tank in the middle, terminated by inlet and outlet DN 25. Cooling zones (duplicators) are equipped necks for deaeration and sludge removal. $[1,2]$

Cooling duplicators are designed as non-pressure and this must be taken into account when connecting to the circuit. A maximum overpressure of $0.5 \mathrm{bar}$ is permitted in the duplicator. The inlet pipe must be fitted with a suitable fitting for regulation, pressure measurement and a suitable safety valve, which must have an opening overpressure set at 0.5 bar. Without meeting this condition, the stability of the vessel shell may be lost and the entire vessel may be destroyed due to exceeding the specified maximum overpressure in the duplicator. The most suitable for these applications is stainless steel. One of the main reasons is its strength, which it retains at both very high and very low temperatures.

Stainless steel is one of the most hygienic materials and is not conducive to the growth of bacteria and other pathogens. As stainless steel is easy to maintain and clean, it is an ideal choice for the food industry, including brewing. This metal stands strong against corrosion, rust and water stains. This also makes stainless steel ideal for any area where there may be temperature and pressure extremes, making it one of the most durable metals on the market.

The results of the work have a verified applicability of commercial software PVESS for the calculation of pressure stainless steel vessels, resp. brewery tanks compared to a lengthy and efficient calculation according to standards in the Czech Republic $[3,4]$.

\section{Research}

According to the regulations, there was a need on the European continent to start prescribing pressure vessels after World War II, when it was necessary to restore a decimated economy throughout Europe, and therefore there was a great demand for vessels in almost all sectors. At that time, individual states began to introduce their own regulations, for example: in 
France the CODAP - French Code for Construction of Unfired Pressure Vessels was created, England at that time introduced the regulation BS 5500 - British standard - Unfired Fusion Welded Pressure Vessels, the former BRD created the regulation AD - Merkblatt, similar regulations are created in Austria, Switzerland, etc. In the countries of the former CMEA, a regulation is being created, which individual states from the CMEA issued under their own name, eg Russia - GOST standard, in our republic the ČSN 690010 standard is being introduced, as it was introduced in the 1970s until 1985. It was completely amended in 1990 and is still valid today [3].

According to Directive (97/23/EC, 1997), issued by the European Parliament in 1997 as the "Directive on the approximation of the laws of the Member States concerning pressure equipment", the so-called PED 97/23 / EC, it is stated that each manufacturer placing pressure equipment on the market must in particular meet the essential requirements for the safety of operation of that equipment. This Directive applies to the design, manufacture and conformity assessment of pressure equipment and assemblies with a maximum working pressure PS greater than 0,5 bar. At the same time, according to this directive, the European harmonized standard EN 13445 - Unheated Pressure Vessels is issued and at the same time the German regulation AD-2000 Merkblatt is harmonized with the PED directive. After joining the European Union, the Czech Republic implemented the PED directive (Government Decree No. 182/1999). This Regulation has been recast into the current Regulation No 621/2004 [5].

The Czech manufacturer must meet NV No. 621/2004 when delivering to the Czech market, where he can choose as a design code for the design of the vessel either ČSN 690010 or EN 13445. When delivering to European Union countries must choose EN 13445 or AD-2000 Merkblatt or ASME code as the design code [6].

Currently, analytical calculations are used for the design of pressure vessels according to standards (eg ISO, EN, ČSN) and no one has dealt with the use of commercial software for dimensioning, material design and strength control of lager tanks.

In the past, the authors dealt with the calculations of pressure vessels in a number of other scientific works, which helped in solving this work [7-16].

\section{Lager tank construction}

The lager tank is a pressure vessel in which the pressure is caused on the one hand by the actual fermentation process of the beer, where carbon dioxide is released, and on the other hand by pushing the beer out of the vessel for further processing. During the final fermentation of the beer, the increasing pressure is permanently released by a shut-off device set by the operator. The choice of the overpressure is governed by the conditions during the final fermentation and is determined in the technology for the production of beer. Usually the barrier pressure does not exceed 0.9 bar. The barrier device is designed for a maximum barrier pressure of 0.2 to $2.4 \mathrm{bar}$ (see description of the barrier device). The contents of the tank are emptied by means of compressed air supplied to the tank via the piping of the barrier valve.

The lager tank is a dedicated pressure device and must be equipped with appropriate safety devices against the occurrence of higher than specified overpressure and against the occurrence of underpressure, which is provided by the customer with regard to the design documentation of the production technology.

The construction of the vessel, its parameters and sockets for connection are based on the project assignment with regard to the technology of the production process. It is a horizontal cylindrical pressure vessel designed for a maximum design overpressure of 3 bar (working overpressure is set at 2.5 bar), which is mounted on two supports (seats) - see (Fig. 1). From the front, the tank is equipped with a manhole, a sampling tap DN 8 and a thermometer well to control the internal temperature. In the front part of the cylindrical shell there is a DN 65 outlet (filling) neck at the bottom and in the upper part there is a DN 20 inlet for the connection of the barrier fitting. There are also two entrances to the tank in the upper part for the sanitation head. The sanitation supply is made from the front of the tank approx. $1500 \mathrm{~mm}$ from the ground via a DN 32 damper.

The lower tank is mounted on two supports (saddles) with a structure adapted to store the upper tanks. The upper tank is mounted on two supports (saddles) on the structure of the support of the lower tank. [17, 18]

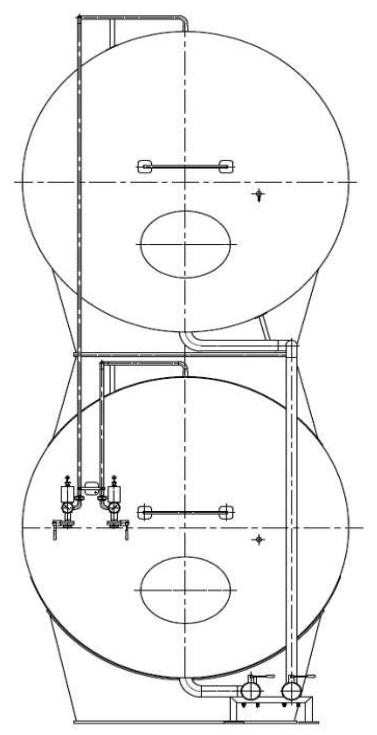

Fig. 1 Sketch of storing tanks 
The actual tank vessel, including the necks, is a weldment made of sheets, arched bottoms, pipes, fittings and fittings made of stainless steel 1.4301 or 1.4541. The sockets and technological pipes are made of material 1.4301 or 1.4541 . The welds are made automatically and manually, respecting the principles for the production of pressure vessels according to $\mathrm{NV}$ No. 93/2015 (formerly PED 97/23 / EC) and ČSN 690010 . From the inside of the vessel, the welds are ground to the required roughness. An EPDM seal is used to seal the flanges. [18]

Stainless steel is a good choice for environmental sustainability due to its properties such as better strength, re-sulting in material savings. It is also more suitable for the food industry. Its use is also more environmentally frien-dly, as it does not cause rusting and the resulting necessary maintenance and environmental pollution [19].

The design of the vessel meets the conditions for the design and manufacture of pressure vessels according to NV No. 93/2015 and further according to ĆSN 690010 and also meets the conditions of the EC Commission Regulation No. 2023/2006 on good manufacturing practice for food contact equipment. The materials are selected so as to meet the hygienic requirements for products intended for contact with food according to Annex No. 8 of Decree MZ38 / 2001 Coll. and further according to EC Regulation No. $1935 / 2004$. Strength is proven by calculation. The material is selected on the basis of experience from the operation of similar equipment in accordance with the customer's requirements. The vessel is not designed for the possibility of a sudden vacuum during sanitation, where this danger arises from the chemical reaction of a weak solution of lye with residual carbon dioxide. The vessel must be perfectly ventilated before the start of the sanitation process, and the actual sanitation process can only be started after the tank has been flushed with water through the sanitation heads. The vessel is not designed for external overpressure from the overpressure of the cooling water in the duplicator, the maximum overpressure in the duplicator is set at 0.5 bar. In accordance with the needs of the production technology, the vessel is equipped with a shut-off device for damaging the fermentation process on the compressed gas supply line. The barrier device is not a pressure relief valve in the sense of ČSN 69 0010. The dimensions of the device, the fitting of individual necks and additional equipment correspond to the specifications of the technology designer. It is possible to use compressed air with an overpressure of max. 2.5 bar to displace beer. [18]

During production, tests prescribed according to the production documentation are performed (X-ray of longitudinal and circumferential welds, dimensional inspection and adherence to the established production and welding procedures). Finally, the tank vessel is subjected to a "Construction and First Pressure Test" in the presence of a representative of the authorized person. The pressure test is performed in a horizontal position - with water - with a prescribed test pressure of 4.3 bar, the value of the test overpressure is determined by calculation and is based on the ČSN 690010 standard and NV No. 93/2015. When performing a pressure test in pairs (two means two tanks stacked on top of each other - see Fig. 4), it is necessary to observe this specified condition that the pressure test of the lower tank may only be performed if the upper tank is empty. Failure to comply with this condition could deform the annulus of the arched bottom of the bottom vessel. This condition also applies to regular control pressure tests resulting from CSN 690012 Stable pressure vessels - operational requirements.

A report is issued on the tests performed, which is part of the inspection book of the pressure vessel. If the vessel is equipped with a cooling duplicator, it is subjected to a water tightness test with an overpressure of 0.7 bar, and a report is issued on the test performed. [18]

The individual tanks are handled using suitable suspension belts with a width of min. $200 \mathrm{~mm}$. The belts are placed behind the reinforcing hoops on the tank vessels and are secured against slipping. If the container is not equipped with reinforcing rings, the container's own seats can be used to ensure that the belts slip. The angle formed by the hinge of the belts should not be greater than $45^{\circ}$. The weight of the upper tank is about $1650 \mathrm{~kg}$ and the lower about $2300 \mathrm{~kg}$. The method of handling must be consulted by the assembly organization with the manufacturer. Due to the fact that the device is not equipped with hanging eyes, it is necessary to pay due attention to handling.

The lower tank is set on a pre-prepared base with sufficient load-bearing capacity and anchored over the seats with 4 M24 screws - the front seat is fixed, the rear is sliding. The upper tank is placed on the established lower tank and fastened to the lower tank with the enclosed M20 screws.

The tanks will be fitted with the appropriate fittings and connected to the lager cellar technology. In the rear part of the bearing there are earthing feet, by means of which the whole device is earthed.

After connection to the technological unit, an initial inspection, inspection of all measuring and safety devices is performed before commissioning, and the vessel is tested for leaks with water, working pressure max. 2.5 bar. The cooling duplicator is tested for water tightness with a maximum overpressure of 0.7 bar.

The device may only be operated by a person who is fully acquainted with the conditions specified for the operation of the device, which is developed by the user. During their elaboration, the provisions of the 
standard ČSN 690012 - Stable pressure vessels - operating requirements, as well as the needs of beer production technology in our own brewery are governed.

When drawing up the operating instructions, it is also necessary to take into account the fact that the vessel is designed as a pressure vessel for a working pressure of 3 bar and this pressure must not be exceeded during operation. The container is not designed for the possibility of a sudden vacuum, for example, when changing the sanitation technology. The operating instructions must also be supplemented with a condition for entering the container: "The container may only be entered after it has been completely ventilated and in suitable footwear which will not damage the inner polished surface." [20]

Before filling the container, the hose with the young beer supply must first be connected to the filling neck of the DN 65 container. Furthermore, the flap on the shut-off valve for air extraction during filling must be open. The young beer supply pipe must be secured against a sudden increase in pressure above 3 bar (max. Working overpressure of the lager tank). The pressure could increase after a longer filling time if the operator forgot to open the DN 20 flap at the barrier device. This situation is very unlikely from the point of view of traffic needs, but it is necessary to consider it.

During the final fermentation of the beer, the increasing pressure is permanently released by a barrier device set by the operator. The usual barrier pressure does not exceed 0.9 bar.

When emptying the container, the filter supply line hose must first be connected to the DN 65 container discharge port. Connect the compressed air supply hose (max. Overpressure 2.5 bar) to the damper flap. Open both flaps and empty the container by pushing it with air. [20]

Maintenance consists of a visual inspection of the condition of the equipment, inspection of the seals and the function of the safety and measuring devices located on the pipeline according to the conditions specified for the vehicle.

Regular maintenance of a clean surface in accordance with the principles arising from the hygienic requirements for equipment in the food industry.

Part of the maintenance is also the implementation of inspections and tests according to ČSN 690012 Stable pressure vessels - operational requirements. [21]

The assembly of the lager tank armature is based on many years of experience in the technology of the production process, where the goal is the slow fermentation of residual carbohydrates at low temperatures of $0 \div 2{ }^{\circ} \mathrm{C}$ and the saturation and fixation of $\mathrm{CO}_{2}$ in beer. Another of the more important processes in the lager tank is the clarification of beer and the acquisition of maturity and stabilization.

The fittings are designed for filling and draining, for payment (adjustment) of the amount of overpressure in the tank needed for the correct course of fermentation and maturation of young beer in the lager cellar. It is also equipped with a sampling tap for sampling during the process and a shut-off valve. To control the temperature, a thermometer well is welded in the front bottom, for the possibility of fitting a thermometer.

During the final fermentation of the beer, the increasing pressure is permanently released by a shutoff device set by the operator. The choice of compensating overpressure is governed by the conditions during final fermentation and is determined in the technology for beer production. Usually, the barrier pressure does not exceed 0.9 bar.

The barrier device is designed for a maximum barrier overpressure of 2.4 bar. During discharge, the contents of the tank are emptied by means of compressed air (by pushing), which is fed into the tank via the piping of the barrier valve. The supply air must not have a higher pressure than the permitted operating pressure in the tank - 2.5 bar. The compressed air supply line must have a separate fuse.

The fitting is a system of pipes equipped with a filling and at the same time draining neck DN 65 closed by a flap. Venting nozzle DN 20 with a shut-off pipe, on which a shut-off device with a manometer and a shut-off flap is located. At the front of the tank is a sampling tap DN 8.

The valve is mounted on an established lager tank according to the supplier's installation documentation. It is attached to the tanks via a screw connection and is held by means of pipe sleeves anchored to the front bottom of the tank. Upon agreement with the customer, it is possible to complete the entire fitting at the manufacturer of the lager tank [21].

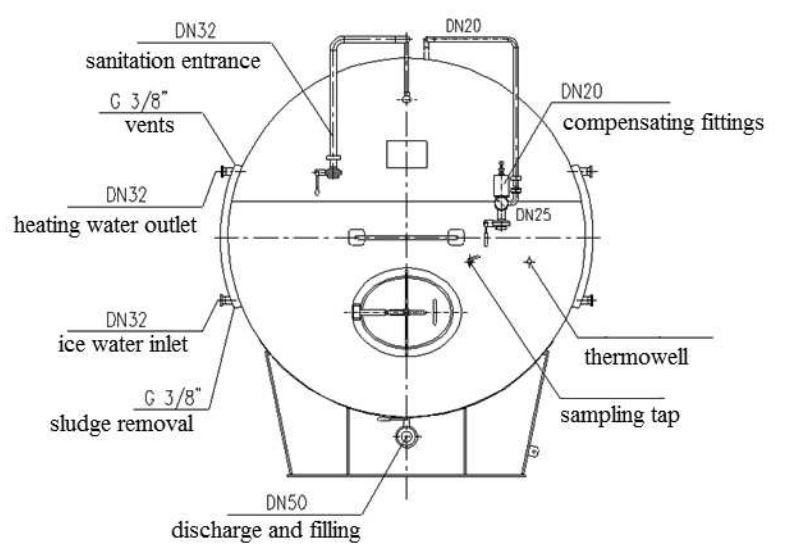

Fig. 2 The overall arrangement of the necks

The choice of a suitable material was based on many years of experience of a company that manufactures appliances and other machinery for breweries and the food industry.

The material must meet at least the following basic 
conditions: sufficient strength, corrosion resistance, have sufficient notched toughness and ductility, guaranteed weldability and comply with the Decree of the Ministry of Health No. 38/2001 Coll. Annex No.8.

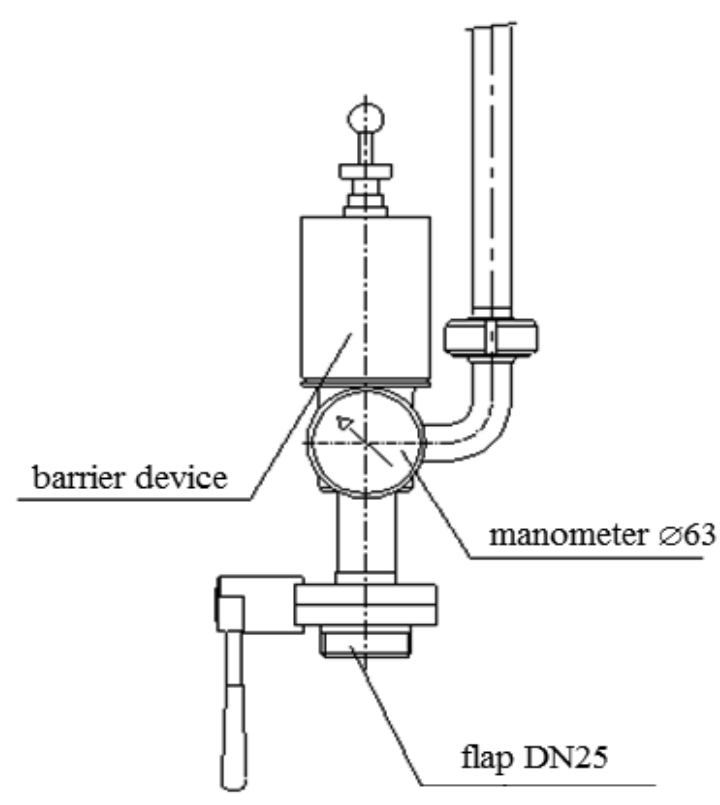

Fig. 3 Barrier fittings

From the above basic criteria, the austenitic stainless steel $\mathrm{X} 5 \mathrm{CrNi} 18-10$ (food steel) was recommended, which is alloyed (Cr $17-19.5 \%$, Ni $8-10.5$, C $<0.07 \%$ ). The steel is marked according to ČSN EN 10088-1 1.4301. The Czech equivalent of this steel, according to the old material designation, corresponds to steel 17240.4 with a chemical composition and with basic physical properties according to the original standard ČSN 417240. A similar foreign steel is known under the designation AISI 304.

According to Government Decree No. 93/2015, Annex No. 1, item 7.5, steels for pressure equipment must meet the condition of a minimum value of ductility, which must be greater than $14 \%$, and its impact work during the bending impact test, measured on a bar with the notch must be greater than 27J at room temperature. This steel meets $\mathrm{X} 5 \mathrm{CrNi}$ 18-10.

The determination of the conformity assessment procedure (determination of the module) is carried out in accordance with $₫ 4 \mathrm{NV}$ No. 93. $\$ 4$, paragraph 1 letter c) applies to the specified category III.

According to $₫ 4$ NV No. 93 for category III, the manufacturer can choose one of the five possible conformity assessment procedures (module). If none of the above modules complies with the manufacturer, it is possible to carry out an overall verification of the unit with module $G$. Module $G$ applies to the strictest category IV. As this is a piece of production of the container, I choose the conformity assessment procedure " $G$ " - verification of the whole according to point
11 of Annex No. 3 to this Regulation. The basic principle in the assessment according to module $G$ is that the manufacturer ensures and declares that the pressure equipment for which it has been issued by an authorized person complies with the provisions of this Regulation that apply to it. Before issuing a certificate, the manufacturer must submit to the authorized person the technical documentation to the following minimum extent:

- a general description of the pressure equipment

- assembly drawing, including detailed drawings of individual parts

- strength calculation

- scope of performed NDT tests on welded joints of the vessel

- welding procedures

- where appropriate, descriptions and explanations necessary for the understanding of the function of the pressure equipment.

Simultaneously with these documents, the manufacturer prepares the accompanying technical documentation (operating instructions, etc.) and prepares the risk analysis.

Based on the assessment of the submitted documentation, the authorized person issues an EC certificate and the manufacturer is obliged to place the $\mathrm{CE}$ mark on the product on the basis of the issued certificate. Only then can the manufacturer place the device on the market.

The basic requirements for the construction of pressure vessels are given in Annex No. 1 to NV 93. The main requirements include the correct design of the entire equipment with emphasis on the overall safety of the vessel for the entire considered service life. These requirements include:

- sufficient strength and stability of the vessel, which must be demonstrated by a correctly chosen calculation method

- taking into account the internal overpressure, or determining the reaction forces and moments caused by the supports and fixing of the pipe parts on the vessel

- taking into account corrosion or erosion, etc.

In order to demonstrate sufficient strength of the container, the base material must be suitably selected with regard to its mechanical properties - sufficient yield strength at design temperature, tensile strength and, if required, sufficient notched toughness of the material, good weldability [21]. 


\section{Measurement results and calculation}

For the strength calculation of the lager tank, it is first necessary to determine the basic geometric dimensions of the vessel (length of the cylindrical part) with these input dimensions, which are entered by the company Sekos Ústí nad Labem s.r.o. (Fig. 4)

For geometric design of the container the basic entered parameters such as the total volume and the outer diameter of the tank, it is necessary to calculate the volumes of individual components and the length of the cylindrical vessel.

Tab. 1 Basic parameters

\begin{tabular}{|l|c|}
\hline \multicolumn{2}{|c|}{ Basic parameters } \\
\hline Container diameter & $2000 \mathrm{~mm}$ \\
\hline Container length & $5600 \mathrm{~mm}$ \\
\hline Total volume & $16.65 \mathrm{~m}$ \\
\hline Estimated weight of the lower tank & $2300 \mathrm{~kg}$ \\
\hline Estimated weight of the upper tank & $1650 \mathrm{~kg}$ \\
\hline $\begin{array}{l}\text { Internal working overpressure and working tempera- } \\
\text { ture }\end{array}$ & $0.25 \mathrm{MPa}, 5^{\circ} \mathrm{C}$ \\
\hline Calculated overpressure and calculated temperature & $0.3 \mathrm{MPa}, 20^{\circ} \mathrm{C}$ \\
\hline
\end{tabular}

Tab 2. Tank equipment

\begin{tabular}{|l|c|}
\hline \multicolumn{2}{|c|}{ Tank equipment } \\
\hline Input/output & $\mathrm{DN} 65$ \\
\hline Sanitation supply & $\mathrm{DN} 32$ \\
\hline Sanitation entry into the tank & $2 \times \mathrm{DN} 20$ \\
\hline Barrier fittings & $\mathrm{DN} 20$ \\
\hline Sampling tap & $\mathrm{DN} 8$ \\
\hline Thermometer well & $\mathrm{G}^{1 / 2}{ }^{\text {" }}$ \\
\hline Oval manhole & $340 \times 470 \mathrm{~mm}$ \\
\hline The inner surface of the container & $\mathrm{Ra}=0.8 \mu \mathrm{m}$ \\
\hline
\end{tabular}

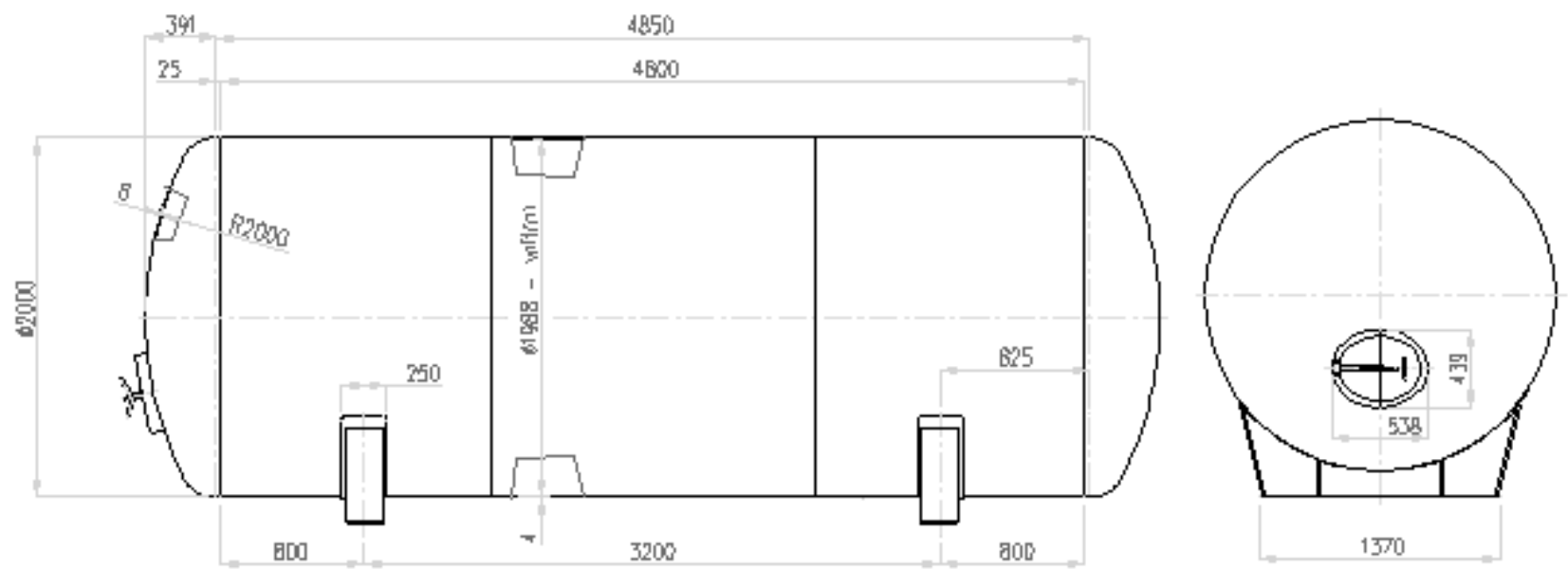

Fig 4. Geometric dimensions of the container

To the bottom volume calculation selected deep arched bottom according to DIN 28011 type A.

To calculate the basic dimensions, authors choose a bottom thickness of $6 \mathrm{~mm}$, height of the cylindrical edge of the bottom $h_{1} \geqslant 3.5 \cdot \mathrm{s}$.

$$
\begin{gathered}
V_{1}=0.1 \cdot\left(d_{a}-2 s\right)^{3} \\
V_{1}=0.1 \cdot(2-2 \cdot 0.006)^{3} \\
V_{1}=0.786 \mathrm{~m}^{3}=786 \mathrm{dm}^{3}
\end{gathered}
$$

where $d_{a}$ - outer diameter of the bottom, $s$ - thickness of the bottom
Calculation of the volume of a cylindrical vessel

$$
\begin{gathered}
V_{\text {válce }}=V_{\text {celk }}-2 \cdot V_{1} \\
V_{\text {valce }}=16.65-2 \cdot 0.786 \\
V_{\text {valce }}=15.07 \mathrm{~m}^{3}=15070 \mathrm{dm}^{3}
\end{gathered}
$$

Calculation of the length of the cylindrical vessel

$$
\begin{aligned}
& l_{\text {valce }}=\frac{4 \cdot V_{\text {valce }}}{\pi \cdot d_{a}^{2}} \\
& l_{\text {valce }}=\frac{4 \cdot 15.07}{\pi \cdot 2^{2}} \\
& l_{\text {válce }}=4.8 \mathrm{~m}
\end{aligned}
$$


Determination of the weight of the container during operation

$$
G_{1}=V \cdot \rho=16.65 \cdot 1000=16650 \mathrm{~kg}=166500 \mathrm{~N}
$$

container weight (assumption), medium weight (water, beer)

Tab. 3 Weights of individual parts

\begin{tabular}{|l|c|}
\hline Bottom (catalog value) & $197.5 \mathrm{~kg}$ \\
\hline Plastic & $960 \mathrm{~kg}$ \\
\hline Manhole and fittings & $45 \mathrm{~kg}$ \\
\hline Total & $1400 \mathrm{~kg}$ \\
\hline
\end{tabular}

$$
G_{2}=1400 \mathrm{~kg}=14000 \mathrm{~N}
$$

total weight of the container (assumption) $G_{h}=$ $G_{1}+G_{2}=166500+14000=180500 \mathrm{~N}$

Support force

$$
\begin{gathered}
F=\frac{G}{n} \\
F=\frac{180500}{2} \\
F=90250 \mathrm{~N}
\end{gathered}
$$

$k$ Coefficient calculation

$$
\begin{gathered}
k=\frac{0.5 \cdot b}{r} \cdot \sqrt{\frac{s}{r}} \\
k=\frac{0.5 \cdot 250}{1000} \cdot \sqrt{\frac{4}{1000}} \\
k=0.0079
\end{gathered}
$$

where $s$ - shell thickness, $r$ - container radius, $b$ saddle width $\boldsymbol{f}_{\varphi}$ Coefficient calculation

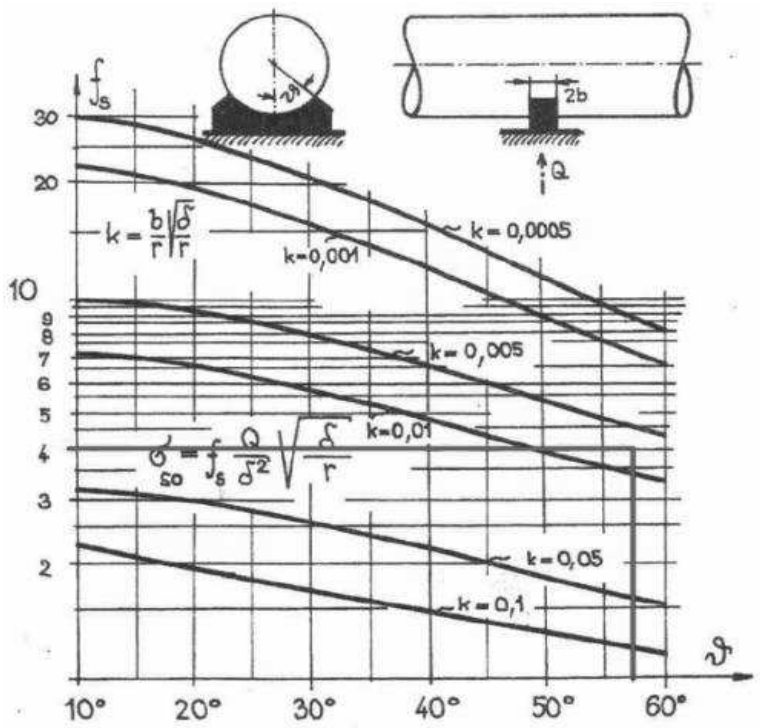

Fig. 5 Diagram for determining the f $\varphi$ coefficient, where coefficient $f \varphi=4[18]$

Determination of allowable stress and at calculated temperature

$$
[\sigma]=\min \left\{\frac{R_{p 1,0}}{n_{T}} ; \frac{R_{m}}{n_{B}}\right\}
$$

$$
\begin{gathered}
{[\sigma]=\min \left\{\frac{250}{1,5} ; \frac{520}{2,2}\right\}} \\
{[\sigma]=\min \{166.7 ; 236.4\}} \\
{[\sigma]=166.7 \mathrm{MPa}}
\end{gathered}
$$

The length of the overhanging part of the equivalent container

$$
\begin{gathered}
a_{e}=a+0.6 \cdot H \\
a_{e}=800+0.6 \cdot 385 \\
a_{e}=1031 \mathrm{~mm}
\end{gathered}
$$

Auxiliary value for determining the reduction factor

$$
\frac{a_{e}}{r} \cdot \sqrt{\frac{s}{r}}=\frac{1031}{1000} \cdot \sqrt{\frac{4}{1000}}=0.065
$$

for this value and angle $\vartheta=57^{\circ}$ subtract the reduction factor from the graph $k_{a}$

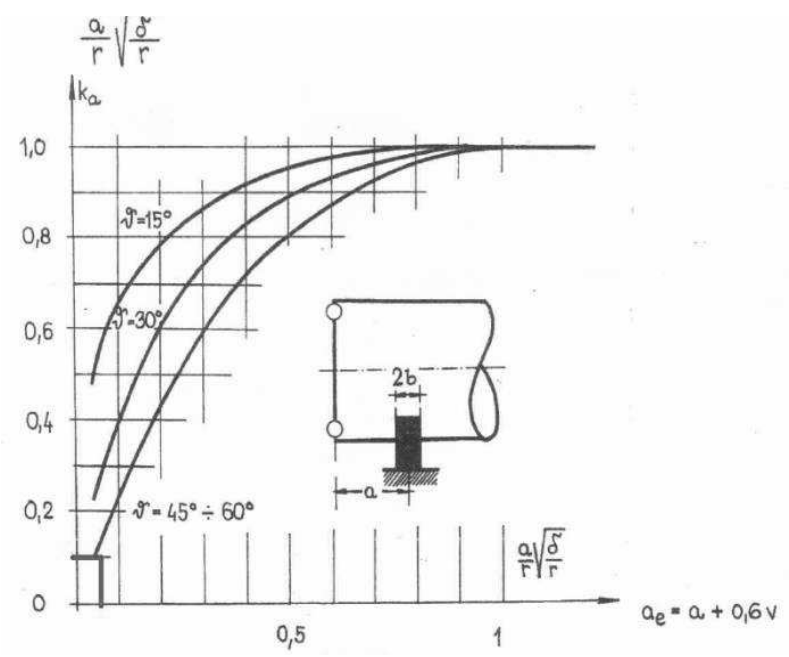

Fig. 6 Diagram for determining the ka coefficient (Where coefficient ka $a=0,1)[18]$

Calculation of bending stress considering reinforcing effects dished $\sigma_{\phi}=k_{a} \cdot \sigma_{\phi o}$

$$
\begin{gathered}
\sigma_{\phi}=0.1 \cdot 1426.98 \\
\sigma_{\phi}=142.7 \quad M P a \\
{[\sigma] \geq \sigma \varphi} \\
{[166.7] \geq 142.7 \mathrm{MPa}}
\end{gathered}
$$

The permissible stress condition is satisfactory

From the stated strength conditions $[\sigma] \geq \sigma \varphi$ it follows that the thickness of the casing made ( $s=4$ $\mathrm{mm}$ ) is satisfactory at the point of support. Because the calculation is solved for an absolutely rigid seat, the magnitudes of the stresses are on the side of higher safety, where the differences between the free and ri- 
gid seat are obvious. The exact assessment of the influence of the saddle on the stiffness of the casing depends on a large number of variables (belt angle, thickness of the base plate, the actual stiffness of the saddle, etc.). Therefore, it is wrong to calculate this task only using special software, which takes into account variables in the calculation, such as the COSMOS program - finite element solution, or software that solves pressure vessels such as PVESS, OHMTECH PRESSURE VESSEL, SANT-AMBROGIO.

Horizontal container placed on 2 steel supports - lower tank

Type of construction: identical design of both supports, supports without reinforcing rings and without base plates, identical coefficients of circumferential weld values, inconsistent dimensions of all individual casing joints, casing without additional external loads, bottoms without additional external loads, plastic with additional external loads.

Load - basic parameters:

- internal design overpressure $p=0.3 \mathrm{MPa}$

- internal test overpressure $p_{z}=0.43 \mathrm{MPa}$

- modulus of elasticity $E=2.10^{5} \mathrm{MPa}$

- safety factor against loss of stability within the limits of elasticity nu $=2.4$

- working medium temperature $2 \div 5^{\circ} \mathrm{C}$

- design temperature $20^{\circ} \mathrm{C}$

- calculated length of the smooth shell $l=5106$ $\mathrm{mm}$

- bulk density of the wall material $\varrho_{d}=8000$ $\mathrm{kg} / \mathrm{dm} 3$

- bulk density of the working substance for operation and testing $\varrho_{z}=1000 \mathrm{~kg} / \mathrm{dm}^{3}$

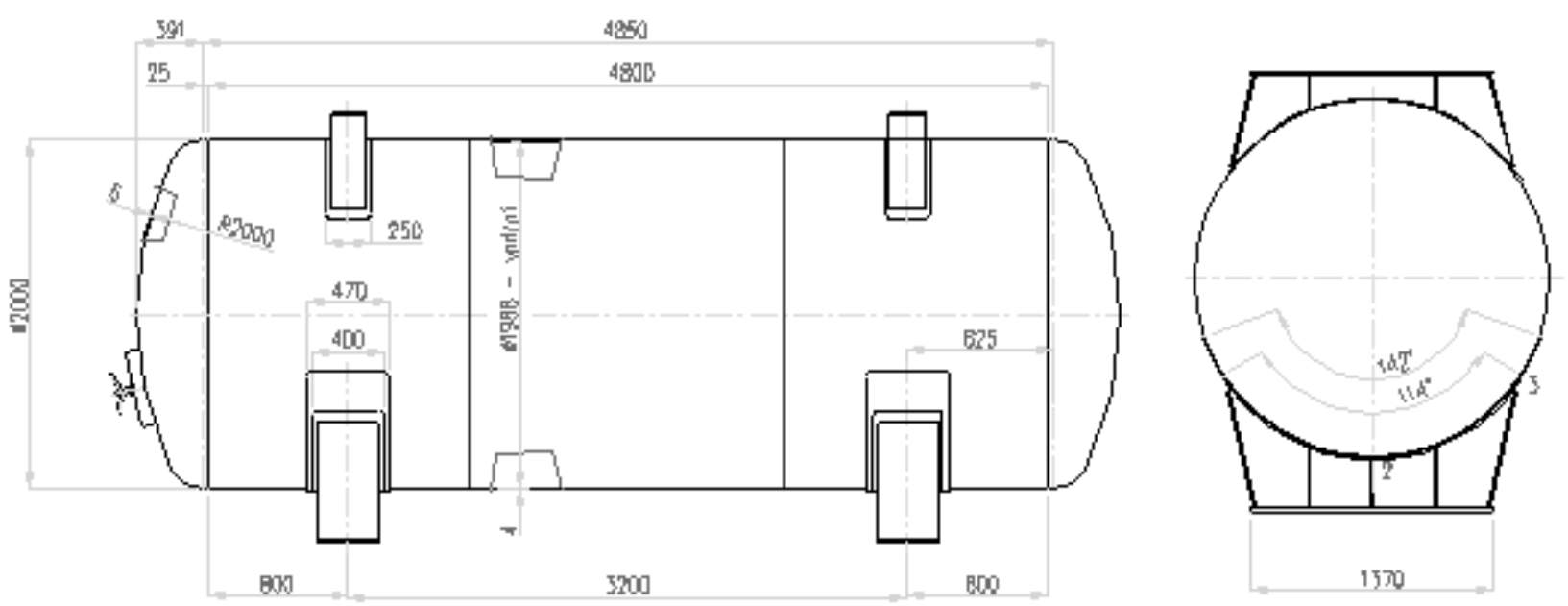

Fig. 7 Geometric dimensions of the bottom tank a) front view, b) side view

Dimensions of arched bottoms, saddles and their layout

Tab. 4 Dimensions of individual parts

\begin{tabular}{|l|l|l|}
\hline Part names & \multicolumn{1}{|c|}{ Markings and units } & Dimensions \\
\hline Inner diameter of the bottom & $D_{b}[\mathrm{~mm}]$ & 1988 \\
\hline Internal height of the bottom arch & $H[\mathrm{~mm}]$ & 385 \\
\hline Length of the cylindrical hem of the bottom & $L_{h}[\mathrm{~mm}]$ & 25 \\
\hline $\begin{array}{l}\text { The length of the left overhanging part of the container, } \\
\text { including the cylindrical rim of the bottom }\end{array}$ & $e_{1}[\mathrm{~mm}]$ & 825 \\
\hline $\begin{array}{l}\text { The length of the left overhang of the equivalent conta- } \\
\text { iner }\end{array}$ & $e_{3}[\mathrm{~mm}]$ & 1081 \\
\hline $\begin{array}{l}\text { Maximum distance between two stably effective casing } \\
\text { reinforcements }\end{array}$ & $l[\mathrm{~mm}]$ & 5106 \\
\hline $\begin{array}{l}\text { Length of the cylindrical shell, including the cylindrical } \\
\text { parts of the bottom }\end{array}$ & $L[\mathrm{~mm}]$ & 4850 \\
\hline Saddle belt wrap angle & $\delta_{1}\left[{ }^{\circ}\right]$ & 114 \\
\hline Wrap angle of the base plate & $\delta_{2}\left[{ }^{\circ}\right]$ & 142 \\
\hline Saddle support width & $b_{1}[\mathrm{~mm}]$ & 250 \\
\hline Base plate width & $b_{2}[\mathrm{~mm}]$ & 470 \\
\hline Backing plate thickness & $s_{2}[\mathrm{~mm}]$ & 6 \\
\hline
\end{tabular}


Calculation of the resulting force

The resulting force acts on the supports of the

$$
G_{1}=V \cdot \rho=16.65 \cdot 1000=16650 \mathrm{~kg}=166500 \mathrm{~N}
$$

lower tank. Determination of the weight of the upper container during operation, medium weight (water, beer).

Container weight (assumption)

Tab. 5 Dimensions of individual parts

\begin{tabular}{|l|l|}
\hline Bottom (catalog value) & $197.5 \mathrm{~kg}$ \\
\hline Plastic & $960 \mathrm{~kg}$ \\
\hline Manhole and fittings & $45 \mathrm{~kg}$ \\
\hline Seat weight & $500 \mathrm{~kg}$ \\
\hline Total & $1900 \mathrm{~kg}$ \\
\hline
\end{tabular}

$$
G_{2}=1900 \mathrm{~kg}=19000 \mathrm{~N}
$$

Total weight of the container (assumption) - additional load

$$
G_{s}=G_{1}+G_{2}=166500+19000=185500 \mathrm{~N}
$$

Exposure of additional external load of the cylindrical shell of the vessel the distance of the left edge of the loaded field from the reference plane $x \mathrm{R}(\mathrm{i})$

Tab. 6 Additional load

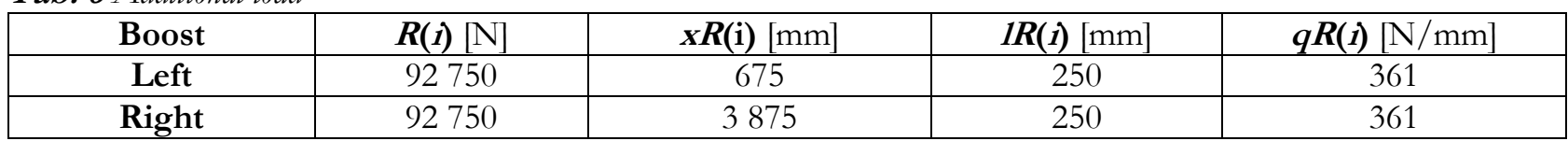

Total resultant force:

$$
G_{c}=G_{h}+G_{s}=180500+185500=366000 N
$$

Support forces $F=\psi \cdot \frac{G_{c}}{n}$

$$
\begin{gathered}
F=1 \cdot \frac{366000}{2} \\
F=183000 \mathrm{~N}
\end{gathered}
$$

coefficient $\psi=1$, for 2 supports $(n=2)$

\subsection{Determination of moments and shear forces}

In determining the resulting shear forces and moments, the basis load of the vessel's own weight, the weight of the medium and the additional loads are taken into account. The resulting forces are determined according to the diagram of the displacement forces of the mechanical system, which is included in the calculation program PVESS in the module T4215D. The calculation of these forces and moments is not included in the standard ČSN 690010 part 4.21, and therefore it is necessary to use the output values from the PVESS program to check the bearing capacity and stability of the lower tank shell from its own load and additional load arising from its own weight. of the upper tank and the weight of the medium in the upper tank. This load is transferred to the lower tank via the saddles.
Total moment at the place of support

$$
M_{1}=M_{2}=0.2227 \cdot 10^{8} \mathrm{Nmm}
$$

Maximum torque between supports

$$
M_{12}=-0.2293 \cdot 10^{8} \mathrm{Nmm}
$$

Shear force acting at the point of support

$$
Q=-0.1003 \cdot 10^{6} \mathrm{~N}
$$

Bottom distance parameter $\gamma=2.83 \cdot \frac{e_{1}}{D} \cdot \sqrt{\frac{s-c}{D}}$

$$
\begin{gathered}
\gamma=2.83 \cdot \frac{825}{1988} \cdot \sqrt{\frac{4-0.3}{1988}} \\
\gamma=0.05
\end{gathered}
$$

Support seat width parameter $\beta=0.91 \cdot \frac{b_{2}}{\sqrt{D \cdot(s-c)}}$

$$
\begin{gathered}
\beta=0.91 \cdot \frac{470}{\sqrt{1988 \cdot(4-0.3)}} \\
\beta=4.98
\end{gathered}
$$


Basic axial membrane stress caused by bending the container at the support point $\bar{\sigma}_{m x}=\frac{4 \cdot\left|M_{1}\right|}{\pi \cdot D^{2} \cdot(s-c)}$

$$
\begin{gathered}
\bar{\sigma}_{m x}=\frac{4\left|0.2227 \cdot 10^{8}\right|}{\pi \cdot 1988^{2} \cdot(4-0.3)} \\
\bar{\sigma}_{m x}=1.94
\end{gathered}
$$

\section{Summary}

In the practical part, the strength calculation of lager tanks was performed, which was performed theoretically, according to the standard and using the computer program PVESS. Furthermore, a comparison of the results is made in the tables. Only critical values are deducted from the PVESS in the tables.

A preliminary theoretical design of the upper tank was made. The calculation of the shell of the lower tank at the seat, which is additionally loaded by the upper tank, was omitted in view of the above-mentioned problems. The calculation was started directly according to the ČSN 690010 standard, which takes more into account the stiffness of the saddle and the subsequent calculation and control using the PVESS program.

The next part contains individual calculations of the main components of the tank. Calculation of the thickness of the arched bottom in three areas (central, transition and cylindrical area) with subsequent control of the allowable internal overpressure. In the same way, the shell thickness was calculated, including the effect of longitudinal welding. Furthermore, inspections of the reinforcement of the necks (outlet) in the casing and inspection of the manhole welded into the arched bottom in the central area were performed. The last task was to assess the strength and stability of the tank shell at the location of the seats and at the location of the largest bending moment. The calculation is performed for the upper and lower tank.

\begin{tabular}{|c|c|c|c|}
\hline Size & Standard & Software & Deviation $[\%]$ \\
\hline \multicolumn{4}{|l|}{ Arched bottom } \\
\hline Permissible internal overpressure $[\mathbf{P}][\mathrm{MPa}]$ & 0.36 & 0.368 & -2.17 \\
\hline Permissible internal overpressure for pressure test $[\mathrm{Pzk}][\mathrm{MPa}]$ & 0.49 & 0.501 & -2.19 \\
\hline \multicolumn{4}{|l|}{ Cylindrical part } \\
\hline Permissible internal overpressure $[\mathrm{P}][\mathrm{MPa}]$ & 0.41 & 0.408 & 0.49 \\
\hline Permissible internal overpressure for pressure test $[\mathrm{Pzk}][\mathrm{MPa}]$ & 0.56 & 0.558 & 0.35 \\
\hline \multicolumn{4}{|l|}{ Upper tank } \\
\hline Support forces $\mathrm{F}[\mathrm{N}]$ & 90250 & 88500 & 1.94 \\
\hline Moment in the place of support $\mathrm{M} 1[\mathrm{Nmm}]$ & 19631824.8 & 19310000 & 1.64 \\
\hline Moment between supports M12 [Nmm] & 23585553.3 & 22930000 & 2.78 \\
\hline Effective force at the point of support $\mathrm{Fe}[\mathrm{N}]$ & 176071.6 & 172900 & 1.8 \\
\hline Allowed support force at the point $2[\mathrm{~F}] 2[\mathrm{~N}]$ & 263971.6 & 263300 & 0.25 \\
\hline Allowed support force at the point $3[\mathrm{~F}] 3[\mathrm{~N}]$ & 187224.5 & 185600 & 0.86 \\
\hline The resulting allowable support force $[\mathrm{F}][\mathrm{N}]$ & 187224.5 & 185600 & 0.86 \\
\hline Condition of strength at the point of support [-] & 0.48 & 0.4769 & 0.64 \\
\hline Checking the stability of the casing at the point of support [-] & 0.16 & 0.1606 & -0.37 \\
\hline Condition of strength between supports [-] & 0.306 & 0.315 & -2.85 \\
\hline Checking the stability of the casing between the supports $[-]$ & 0.03 & 0.0289 & 3.66 \\
\hline \multicolumn{4}{|l|}{ Bottom tank } \\
\hline Effective force at the point of support $\mathrm{Fe}[\mathrm{N}]$ & 351813.3 & 358600 & -1.89 \\
\hline Allowed support force at the point $2[\mathrm{~F}] 2[\mathrm{~N}]$ & 330264.4 & 320700 & 2.89 \\
\hline Allowed support force at the point & 443153.2 & 438200 & 1.11 \\
\hline The resulting allowable support force $[\mathrm{F}][\mathrm{N}]$ & 330264.4 & 320700 & 2.89 \\
\hline Condition of strength at the point of support [-] & 0.55 & 0.5722 & -3.88 \\
\hline Checking the stability of the casing at the point of support [-] & 0.33 & 0.3326 & -0.78 \\
\hline Condition of strength between supports [-] & 0.304 & 0.315 & -3.49 \\
\hline Checking the stability of the casing between the supports [-] & 0.03 & 0.0289 & 3.66 \\
\hline
\end{tabular}

Tab. 7 Summary and comparison of results

\section{Conclusion}

The article dealt with the design of lager tanks, which are used to mature beer. By checking the strength calculation, the correctness of the proposed construction of lager tanks was verified.
The comparison of the results shows that the upper and lower tanks are safe in terms of strength and stability. The most critical component in terms of internal overpressure is the arched bottom in the transition area, where the allowable internal overpressure is 
$0.36 \mathrm{MPa}$ compared to the working overpressure of $0.3 \mathrm{MPa}$, there is a reserve of about $17 \%$, which is fully satisfactory.

In the case of the strength and stability of the shell, the determining condition of the strength at the point of support is expressed by the relation $0.48 \leqslant 1$. It follows from the above that the shell of the tank has twice the safety.

For the lower tank, at the point of support, this value is expressed by the relation $0.55 \leqslant 1$ and in this case the safety is approximately 1.8 .

The results of the work proved the suitability of using the PVESS software for calculating the strength of brewery pressure vessels. The results of the work were evaluated as satisfactory for further use in the design of pressure vessels. The maximum deviation of the calculation using the PVESS program was $3.88 \%$, the mean value of the deviation is $2.22 \%$.

The results of the work confirmed the usability of commercial software PVESS for dimensioning, material design and strength control of lager tanks. We have thus confirmed the accuracy of the calculation results using a commercial program for the calculation of pressure vessels.

\section{Acknowledgement}

The article was created with the contribution of SGS grant support - Jan Evangelista Purkyně University in Ústí nad Labem UJEP-SGS-202048-001-2.

\section{References}

[1] HLAVÁČEK, F., LHOTSKÝ, A. (1972). Pivovarství, SNTL, Praha 1972

[2] CHLÁDEČEK, L. (2007). Pivovarnictví, Grada, Praha 2007

[3] ČSN EN 10028-7 Ploché výrobky z ocelí pro tlakové účely, 2017

[4] 1997 ČSN EN 286-1 Tlakové nádoby stabilní, platnost od 1999 do současnosti

[5] Směrnice 97/23/ES evropského parlamentu a rady z 29. května

[6] BABINSKÝ, M. (1995). Pevnostní výpočty tlakových nádob, 1995

[7] CISZAK, O., JUSZKIEWICZ, J., SUSZYŃSKI, M. Programming of Industrial Robots Using the Recognition of Geometric Signs in Flexible Welding Process. Symmetry 2020, 12, 1429. https://doi.org/10.3390/sym12091429

[8] SVOBODA, M., SOUKUP, J. (2013). Verification of Numeric Solution by Experiment for
Examination Verti-cal Osci-llation of a Mechanical System. In: Manufacturing Technology, Vol. 13, No. 4 (2013) pp 559-563, ISSN: 1213-2489

[9] SAPIETA, M., ŠULKA, P., SVOBODA, M. (2018). Using a numerical model to verification of thermoelastic analysis of flat specimen, In: Manufacturing Technology, Vol. 18, No. 3 (2018) pp 482-486, ISSN: 1213-2489, DOI: 10.21062/ujep/125.2018/a/1213$2489 / \mathrm{MT} / 18 / 3 / 482$

[10] ČERNOHLÁVEK, V., SVOBODA, M., ŠTĚRBA, J., CHALUPA, M., SAPIETA, M. (2020). Analytical and experimental solution of vibrations of a system of bound bodies. In: $M a$ nufacturing Technology. Vol. 20, No. 6 (2020) pp 699-707. ISSN: 1213-2489. DOI: 10.21062/mft.2020.116.

[11] XIN, Y., ZHOU, Z., LI, M., ZHUANG, C. (2020). Analytical Solutions for Unsteady Groundwater Flow in an Uncon-fined Aquifer under Complex Boundary Conditions. Water 2020, 12, 75 . https://doi.org/10.3390/w12010075

[12] ŠTĚRBA, J., ČERNOHLÁVKOVÁ, V., SOUKUP, J. (2015). Automation of Filling Cryogenic Vessels with Perlite. Manufacturing Technology. 2015;15(5): 941-944. doi: 10.21062/ujep/x.2015/a/12132489/MT/15/5/941.

[13] SVOBODA, A., CHALUPA, M., ŠRÁMKOVÁ, T. (2021). Mechanical Medical Device for Generating Vibration and Stimulation of the Neuron Pathways. Symmetry 2021, 13, 62. https://doi.org/10.3390/sym13010062

[14] SZYBIŃSKI, B., ROMANOWICZ, P. J. (2019). Optimization of Flat Ends in Pressure Vessels. Materials 2019, 12, 4194. https://doi.org/10.3390/ma12244194

[15] CHOI, J., AHN, J.H., KIM, H.Y. (2021). Modeling the Dynamic Behavior of a Pilot-Operated Solenoid Valve for an Ultra-High Pressure Vessel. Appl. Sci. 2021, 11, 2329. https://doi.org/10.3390/app11052329

[16] AGRESTA, A., CAVALAGLI, N., BISCARINI, C., UBERTINI, F. (2021). Effect of Bottom Geometry on the Natural Sloshing Motion of Water inside Tanks: An Experimental Analysis. Appl. Sci. 2021, 11, 605. https://doi.org/10.3390/app11020605

[17] HALADUICK, S., DANN, M. R. (2018). Genetic Algorithm for Inspection and Maintenance Planning of Deteriorating Structural 
Systems: Application to Pressure Vessels. Infrastructures 2018, 3, 32. https://doi.org/10.3390/infrastructures3030032

[18] KŘUPKA, V., SCHNEIDER, P. (1994). Stavba chemických zařziení I, PC-DIR, Brno 1994

[19] KHALIFA, M., YOUSSEF, M.A., ALHADID, M.M.A. (2020). Heat of Hydration Stresses in
Stainless-Steel-Reinforced-Concrete Sections. Sustainability 2020, 12, 4852. https://doi.org/10.3390/su12124852

[20] BOURNE, J. C. E. (2004). A Catechism of the Steam Engine. [s. 1.] : Project Gutenberg, 2004

[21] T-Consult, Tlaková zařízení - pevnostní výpočty, Brno 2008. 